\title{
Effect of inhaled bradykinin on indices of airway responsiveness in asthmatic subjects
}

\author{
R. Polosa*, K. Rajakulasingam**, G. Prosperini*, S. Bellofiore*, S.Britten**, \\ L.V. Milazzo*, S.T. Holgate**
}

Effect of inhaled bradykinin on indices of airway responsiveness in asthmatic subjects. R. Polosa, K. Rajakulasingam, G. Prosperini, S. Bellofiore, S. Britten, L.V. Milazzo, S.T. Holgate. CERS Journals Ltd 1994.

ABSTRACT: Asthma is characterized by airway hyperresponsiveness, a physiopathological abnormality which may result from the complex interplay between inflammatory cells and proinflammatory mediators. Although kinins are thought to play a role in the pathogenesis of bronchial asthma, it is not known whether bradykinin is able to induce airway hyperresponsiveness.

We have, therefore, investigated the effect of inhaled bradykinin on the changes in airway calibre and in airway hyperresponsiveness to histamine, in a double-blind, randomized study of nine asthmatic subjects. Subjects were studied on two study periods, separated by at least 15 days. On the first day of each study period, subjects inhaled either a single dose of bradykinin or methacholine (placebo) with changes in airway calibre being followed as forced expiratory volume in one second $\left(\mathrm{FEV}_{1}\right)$ and as the maximum expiratory flow rate measured at $70 \%$ of the vital capacity below total lung capacity (TLC) from a partial forced expiratory manoeuvre $\left(\dot{\mathrm{V}} \mathbf{p}_{30}\right)$ at 3, 5, 10, 15, 30, 45 and $60 \mathrm{~min}$, and then every hour for $7 \mathrm{~h}$. Airway responsiveness to histamine, expressed as the provocative concentrations producing a $20 \%$ fall in $\mathrm{FEV}_{1}$ and $40 \%$ fall in $\mathrm{Vp}_{30}\left(\mathrm{PC}_{20} \mathrm{FEV}_{1}\right.$ and $\left.\mathrm{PC}_{40} \dot{\mathbf{V}} \mathbf{p}_{30}\right)$, was measured at 3 and $7 \mathrm{~h}$ after inhaling the agonists, then on days $1,3,7$ and 14 .

Inhalation of bradykinin caused rapid bronchoconstriction that peaked at 3-5 min. When compared to placebo, no significant difference in histamine responsiveness was seen after bradykinin in terms of changes in $\mathrm{PC}_{20} \mathrm{FEV}_{1}$ values. However, when airway hyperresponsiveness was measured as $\mathbf{P C}_{40} \dot{\mathbf{V}}_{30}$, we were able to show a significant increase in airway reactivity after bradykinin at 3 and $7 \mathrm{~h}$, the geometric mean $\mathrm{PC}_{40} \dot{\mathrm{V}} \mathrm{p}_{30}$ histamine value decreasing 3.2 and 1.9 fold, respectively.

The results of the present study indicate that bradykinin elicits a transient increase of airway hyperresponsiveness in asthmatic subjects, but this was evident only using a sensitive indicator of the changes in airway reactivity, which suggests an effect at the level of the more peripheral airways. These data suggest that bradykinin may play a role in the pathogenesis of airway hyperresponsiveness in human asthma. Eur Respir J., 1994, 7, 1490-1496.

\begin{abstract}
*Istituto Malattie Apparato Respiratorio, University of Catania, Catania, Italy. **Medicine 1, Southampton General Hospital, Southampton, UK.
\end{abstract}

Correspondence: R. Polosa

Istituto Malattie Apparato Respiratorio

University of Catania

Via Passo Gravina 187

95125 Catania

Italy

Keywords: Asthma

bradykinin

bronchoconstriction

bronchial hyperreactivity

Received: October 191993

Accepted after revision May 151994
Inflammation is a cardinal feature of asthma [1], the clinical expression of which is airway hyperresponsiveness [2]. Airway hyperresponsiveness, the exaggerated bronchoconstrictor response to various stimuli, may be measured in the laboratory with agents such as histamine and methacholine [3], but may also be expressed as enhanced responsiveness to physical stimuli, such as exercise [4] and inhalation of cold air [5]. Methacholine and histamine exert their effect on airways smooth muscle directly via an interaction with the $\mathrm{M}_{3}$ and the $\mathrm{H}_{1}$ receptor, respectively. Although there is a high degree of correlation between the level of hyperresponsiveness determined by the two [3], methacholine is rather different from histamine in not being able to induce vascular responses in the lung. Allergen inhalation results in an increase of airway hyperresponsiveness during natural exposure [6], and in the setting of allergen bronchial challenge, during which most sensitized asthmatic individuals experience both early (EAR) and late (LAR) asthmatic responses [7]. Although the mechanism of this increased airway responsiveness remains unclear, immunoglobulin E (IgE) -mediated production of inflammatory mediators within the bronchial mucosa may contribute to this abnormality [1].

Bradykinin is a naturally occurring vasoactive nonapeptide formed de novo in body fluids and tissues during inflammatory processes. It is generated from circulating kininogens through proteolytic cleavage by a variety of enzymes, the most important of which are tissue and plasma kallikreins [8]. Evidence that kinin generation 
may be increased under conditions which prevail in areas of allergic inflammation in the airways has recently been obtained from studies in asthmatic subjects [9-11]. In addition, bradykinin is reported to possess many pharmacological properties pertinent to the pathogenesis of asthma. These include vasodilatation and increased microvascular leakage $[12,13]$, bronchoconstriction $[14$, 15], modulation of mucociliary transport $[16,17]$, activation of C-fibre nociceptive sensory nerve endings $[16$, 18 ], and induction of nonspecific bronchial hyperresponsiveness in animals [19].

Although the wide array of pharmacological activities possessed by bradykinin may be relevant to inflammatory mechanisms in asthma [20], there is uncertainty about the ability of bradykinin to induce bronchial hyperresponsiveness in man and its clinical significance. As part of a series of studies evaluating the role of bradykinin in asthma, we have investigated the changes in airway calibre and in bronchial reactivity to inhaled histamine, after a single bronchoprovocative dose of bradykinin and methacholine, in a double-blind randomized study on asthmatic subjects.

\section{Methods}

\section{Subjects}

Nine nonsmoking subjects with stable asthma ( 3 males and 6 females) with a mean ( \pm SEM) age of $26 \pm 3$ yrs, participated in the study (table 1). Subjects Nos 1, 6 and 8 had moderately hyperresponsive airways (table 1), but, like the remaining six subjects, they had never experienced any severe exacerbation of their asthma. Seven of the subjects studied were atopic, as defined by positive skin prick tests ( $>2 \mathrm{~mm}$ wheal response) to two or more of five common aeroallergens: mixed grass pollens, Dermatophagoides pteronyssinus, Dermatophagoides farinae, dog hair and cat dander (Bencard, Brentford, Middlesex, UK). Their baseline forced expiratory volume in one second $\left(\mathrm{FEV}_{1}\right)$ was $>75 \%$ of their predicted values, and none had ever received oral corticosteroids or theophylline as treatment. All were controlled on inhaled beta-agonists on an on-demand basis, whereas only three subjects were regular users of inhaled corti- costeroids. Inhaled bronchodilators were withheld for at least $12 \mathrm{~h}$ prior to each visit, but subjects were allowed to continue their inhaled corticosteroids as usual. Subjects were not studied within 4 weeks of an upper respiratory tract infection and all initial visits to the laboratory were carried out at the same time of day $(07.30 \mathrm{~h})$. The study was approved by the Southampton University and Hospitals Ethics Subcommittee and written informed consent was obtained from each subject.

\section{Measurements}

Airway calibre was followed both as the $\mathrm{FEV}_{1}$ and as the maximum expiratory flow rate measured at $70 \%$ of the vital capacity (VC) below total lung capacity (TLC) from a partial forced expiratory manoeuvre (Vp30). Both measurements were derived from flow-volume curves produced on a rolling seal flow-rate-dependent spirometer (Morgan Spiroflow, P.K. Morgan Ltd, Kent, UK) connected to an 85 B desk top computer via an 82940A GP-10 interface (Hewlett Packard, Wokingham, Berkshire, UK). Partial expiratory flow-volume (PEFV) curves were obtained using the technique described by ZAMEL [21]. Briefly, three VC measurements were recorded, and the largest used to define the control VC. The volume from which the PEFV curves were initiated was set at $70 \%$ of this control VC and marked-off from TLC. After at least one minute of tidal breathing, during which deep breaths were carefully avoided, subjects were asked to reach, from end-tidal expiration, a volume equal to $70 \%$ of their control $\mathrm{VC}$, and to expire forcefully to residual volume (RV). In this way, PEFV curves, standardized for volume and volume history, were obtained and related $\dot{V} p_{30}$ values derived. On reaching $R V$, subjects inspired to TLC and then expired maximally back to RV, allowing a measurement of $\mathrm{FEV}_{1}$ to be recorded.

The repeatability of the $\mathrm{Vp}_{30}$ measurements was calculated for each triplicate series by working out the individual coefficient of variation $(\mathrm{CV})(\mathrm{CV}=$ standard deviation/arithmetic mean $\times 100)$ between repeated measurements for each subject. $\mathrm{Vp}_{30}$ measurements were found to be repeatable with individual CVs ranging from 5 to $13 \%$.

Table 1. - Characteristics of the subjects studied

\begin{tabular}{|c|c|c|c|c|c|c|}
\hline $\begin{array}{l}\text { Subject } \\
\text { No. }\end{array}$ & Sex & $\begin{array}{l}\text { Age } \\
\text { yrs }\end{array}$ & $\begin{array}{c}{\text { Baseline } \mathrm{FEV}_{1}}_{\% \text { pred }}\end{array}$ & $\begin{array}{c}\mathrm{PC}_{20} \begin{array}{l}\text { methacholine } \\
\mathrm{mg} \cdot \mathrm{ml}^{-1}\end{array} \\
\end{array}$ & Atopy ${ }^{\S}$ & Medication \\
\hline 1 & $\mathrm{~F}$ & 28 & 75 & 0.65 & + & $\mathrm{S}$ \\
\hline 2 & $\mathrm{M}$ & 31 & 95 & 3.40 & + & $\mathrm{S}$ \\
\hline 3 & $\mathrm{~F}$ & 22 & 86 & 2.25 & + & $\mathrm{S}$ \\
\hline 4 & $\mathrm{~F}$ & 43 & 77 & 1.94 & - & $\mathrm{S}$ \\
\hline 5 & $\mathrm{~F}$ & 24 & 92 & 1.42 & - & $\mathrm{S}$ \\
\hline 6 & $\mathrm{~F}$ & 20 & 89 & 0.68 & + & $\mathrm{S}, \mathrm{Bf}(1,000 \mu \mathrm{g})$ \\
\hline 7 & M & 18 & 104 & 6.42 & + & $\mathrm{S}$ \\
\hline 8 & $\mathrm{~F}$ & 21 & 101 & 0.40 & + & $\mathrm{S}, \mathrm{Bf}(1,000 \mu \mathrm{g})$ \\
\hline 9 & M & 25 & 88 & 2.05 & + & $\mathrm{S}, \mathrm{Bf}(500 \mu \mathrm{g})$ \\
\hline Mean & & 26 & 90 & $1.54 *$ & & \\
\hline SEM & & \pm 3 & \pm 3.3 & $(0.40-6.42)$ & & \\
\hline
\end{tabular}

s: atopic, positive (+) immediate skin test to one or more allergens; $*$ : geometric mean (range); $\mathrm{FEV}_{1}$ : forced expiratory volume in one second; $\mathrm{PC}_{20}$ : provocative concentration producing a $20 \%$ fall in $\mathrm{FEV}_{1}$; $\mathrm{F}$ : female; M: male; $\%$ pred: percentage of prediction; S: inhaled salbutamol (prn); Bf: inhaled beclomethasone $\left(500-1,000 \mu \mathrm{g} \cdot \mathrm{day}^{-1}\right)$ 


\section{Drug administration and bronchoprovocation}

Methacholine, bradykinin and histamine were freshly prepared in $0.9 \%$ sodium chloride (saline) on each occasion, to produce a range of doubling concentrations of $0.03-16.00,0.0039-8.00$ and $0.03-8.00 \mathrm{mg} \cdot \mathrm{ml}^{-1}$, respectively. To avoid loss of bradykinin through peptide degradation and adherence to plastic surfaces, the solutions were stored at $4^{\circ} \mathrm{C}$ until 15 min before inhalation, when the solution was allowed to reach room temperature, and bronchoprovocation was performed within 30 min of preparing the dilutions. On the control study day, a placebo solution consisting of methacholine at a concentration capable of causing a $30 \%$ fall in $\mathrm{FEV}_{1}\left(\mathrm{PC}_{30} \mathrm{FEV}_{1}\right)$ in each subject was prepared in $0.9 \%$ saline. Pharyngeal irritation can occur during inhalation of bradykinin, so some subjects may have been aware that they were receiving the kinin. To minimize the effect on the principal investigator, methacholine and bradykinin solutions were administered by a second investigator in a separate challenge room.

The aqueous solutions were administered as aerosols generated from a starting volume of $3 \mathrm{ml}$ in a disposable Inspiron Mini-neb nebulizer (C.R. Bard International, Sunderland, UK) driven by compressed air at $8 \mathrm{l} \cdot \mathrm{min}^{-1}$. Under these conditions the nebulizer had an output of $0.48 \mathrm{ml} \cdot \mathrm{min}^{-1}$ and generated an aerosol with a mass median particle diameter of $4.7 \mu \mathrm{m}$. Subjects, wearing a noseclip, inhaled the aerosolized solutions in five breaths from end-tidal volume to TLC via a mouthpiece. Subjects were trained to take $3 \mathrm{~s}$ to reach TLC. Before the bronchial challenges, measurements of $\mathrm{FEV}_{1}$ and $\dot{\mathrm{V}} \mathrm{p}_{30}$ were made both before and after inhalation of the vehicle solution.

\section{Study design}

The study consisted of two phases outside the pollen season.
Phase 1. Evaluation of $P C_{20} / P C_{30} F E V_{1}$ to both methacholine and bradykinin. Subjects attended on two visits to the laboratory, at least $72 \mathrm{~h}$ apart, to undertake concentration-response studies with inhaled methacholine and bradykinin. On each occasion, after $15 \mathrm{~min}$ of rest, three baseline measurements of $\mathrm{FEV}_{1}$ were recorded at 3 min intervals. Subjects then inhaled nebulized vehicle diluent solution, and $\mathrm{FEV}_{1}$ measurements were repeated at 1 and $3 \mathrm{~min}$. Provided that the $\mathrm{FEV}_{1}$ did not fall by $>10 \%$ of the baseline value, bronchial provocation testing with one of the two agonist was carried out. After administration of each concentration of agonist, $\mathrm{FEV}_{1}$ was measured at 1 and $3 \mathrm{~min}$, the higher of the two values being recorded. Increasing concentrations of methacholine or bradykinin were inhaled at 5 min intervals, until $\mathrm{FEV}_{1}$ had fallen by $>30 \%$ of the postdiluent baseline value, or until the highest concentrations of agonist had been administered. The percentage decrease in $\mathrm{FEV}_{1}$ from postdiluent baseline was plotted against the cumulative concentration of agonist administered and that concentration of agonist required to produce a 20 and $30 \%$ fall in $\mathrm{FEV}_{1}$ from the postdiluent baseline value $\left(\mathrm{PC}_{20} \mathrm{FEV}_{1}\right.$ and $\mathrm{PC}_{30} \mathrm{FEV}_{1}$ respectively) determined by linear interpolation.

Phase 2. Exposure to $P C_{30} F E V_{1}$ dose bradykinin or methacholine. This consisted of two study periods separated by at least 14 days (fig. 1), during which subjects inhaled either the $\mathrm{PC}_{30} \mathrm{FEV}_{1}$ bradykinin or matched placebo (i.e. $\mathrm{PC}_{30} \mathrm{FEV}_{1}$ methacholine) in a double-blind, randomized manner, to mimic the bronchoconstrictor effect of bradykinin. On the first day of each study period, subjects attended the laboratory at $07.30 \mathrm{~h}$ to undertake a concentration-response study with inhaled histamine, to determine their baseline airways responsiveness. Serial doubling concentrations of histamine $\left(0.03-8.00 \mathrm{mg} \cdot \mathrm{ml}^{-1}\right)$ were administered at $5 \mathrm{~min}$ intervals, followed by measurements of $\dot{\mathrm{V}}_{30}$ and $\mathrm{FEV}_{1}$ at 1 and 3
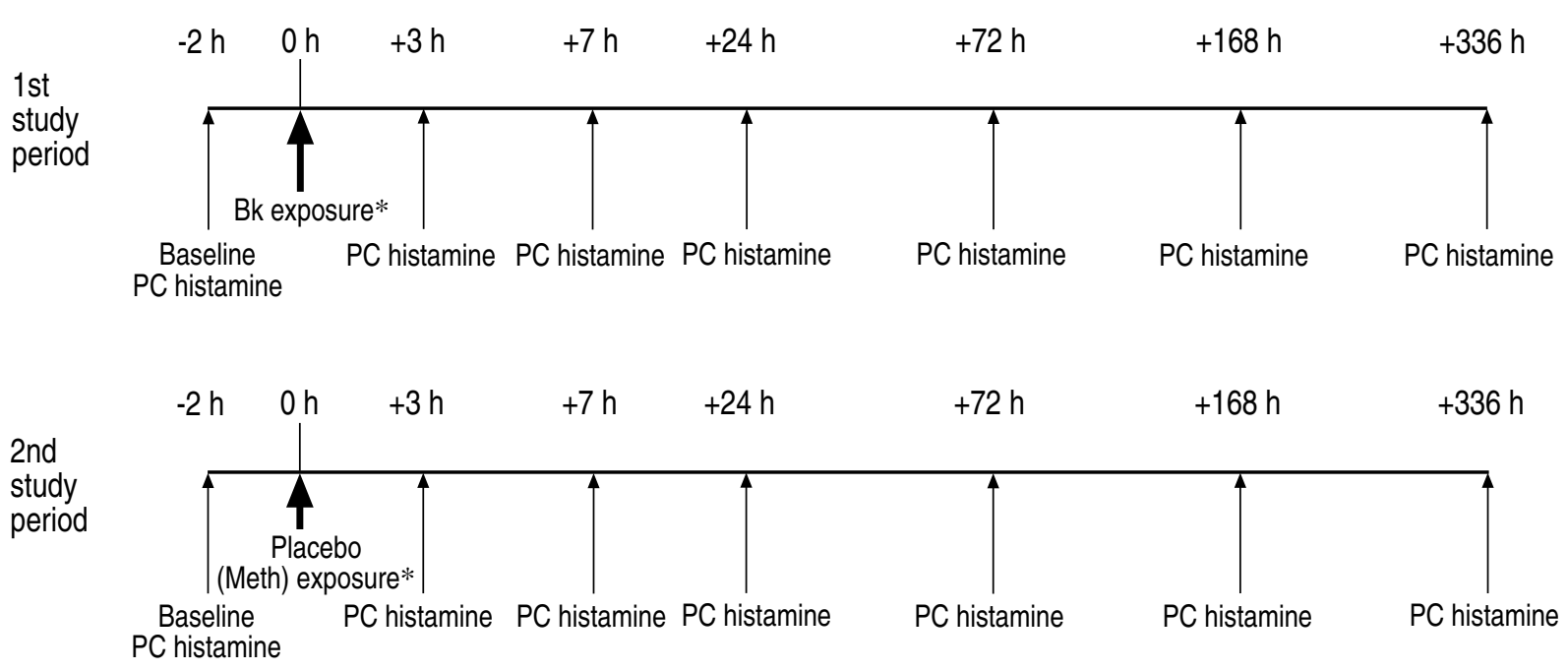

Fig. 1. - Study design. Phase 2 - exposure to $\mathrm{PC}_{30} \mathrm{FEV}_{1}$ dose bradykinin or methacholine. Bk: bradykinin; Meth: methacholine; PC: bronchoprovocation test with inhaled histamine; $\mathrm{PC}_{30} \mathrm{FEV}_{1}$ : provocative concentration producing a $30 \%$ fall in forced expiratory volume in one second. *: the order of bradykinin and methacholine exposures was randomized and double-blind. 
min after inhalation of each dilution. The inhalation and measurements were continued until the $\mathrm{FEV}_{1}$ had fallen by at least $20 \%$ of the postsaline value. Once the $\mathrm{FEV}_{1}$ had returned to within $5 \%$ of the baseline value, (approximately 45-60 min later), the airways response to either placebo (the $\mathrm{PC}_{30} \mathrm{FEV}_{1}$ methacholine) or active drug (the $\mathrm{PC}_{30} \mathrm{FEV}_{1}$ bradykinin) was assessed, with changes in airway calibre being monitored as $\mathrm{FEV}_{1}$ and $\mathrm{Vp}_{30}$ at 3, 5, $10,15,30,45$ and $60 \mathrm{~min}$, and then at every hour for 7 $\mathrm{h}$. Changes in airways responsiveness, expressed as the $\mathrm{PC}_{20} \mathrm{FEV}_{1}$ and the provocative concentration producing a $40 \%$ fall in $\dot{\mathrm{V}} \mathrm{p}_{30}\left(\mathrm{PC}_{40} \dot{\mathrm{V}} \mathrm{p}_{30}\right)$ histamine, were assessed at 3 and $7 \mathrm{~h}$ after inhaling the agonist and then 1, 3, 7 and 14 days after the initial challenge. Thus, one study period comprised 15 days.

\section{Data analyses}

All figures refer to means (+/-SEM) unless otherwise stated, and the $\mathrm{p}<0.05$ level of significance was accepted. At each study period the magnitude of bradykinin- and methacholine-induced bronchoconstriction was quantified as the maximum percentage fall in $\dot{\mathrm{V}} \mathrm{p}_{30}$ and $\mathrm{FEV}_{1}$ achieved within the first $30 \mathrm{~min}$ of challenge and compared by Wilcoxon signed rank test.

Concentration response curves to agonists were constructed by plotting the percentage change in $\mathrm{FEV}_{1}$ and $\dot{\mathrm{V}} \mathrm{p}_{30}$ from baseline against the cumulative concentration of the agonist on a logarithmic scale. $\mathrm{PC}_{20} \mathrm{FEV}_{1}, \mathrm{PC}_{30}$ $\mathrm{FEV}_{1}$ and $\mathrm{PC}_{40} \dot{\mathrm{V}} \mathrm{p}_{30}$ were derived by linear interpolation. To compare the effect of bradykinin and methacholine (placebo) exposure on histamine responsiveness, twoway analysis of variance (ANOVA) followed by the Neuman Keuls procedure was used to analyse the change of the log transformed PC-values observed during bradykinin and control methacholine study periods.

Linear regression analyses were used to determine the relationship between the magnitude of bradykinin-induced bronchoconstriction and the changes in histamine responsiveness. Any relationship between airways responsiveness to bradykinin and that to methacholine, and between maximum falls in $\mathrm{FEV}_{1}$ and $\dot{\mathrm{V}} \mathrm{p}_{30}$ against the corresponding baseline values of histamine $\mathrm{PC}_{20} \mathrm{FEV}_{1}$ and $\mathrm{PC}_{40} \mathrm{Vp}_{30}$ were investigated by least square linear regression. Mann-Whitney U-tests were used to analyse any difference in the airway responses to bradykinin between the moderately hyperresponsive and the mild hyperresponsive subjects and the steroid and nonsteroid users. Similarly, any difference in histamine airway responsiveness after bradykinin exposure between the steroid and nonsteroid users was analysed by Mann-Whitney U-test.

\section{Results}

\section{Effect of bradykinin on the airway calibre}

Inhalation of bradykinin caused rapid bronchoconstriction that peaked at 3-5 min and gradually resolved to within $30 \%$ of baseline $\dot{\mathrm{V}}_{30}$ and $6 \%$ of baseline $\mathrm{FEV}_{1}$
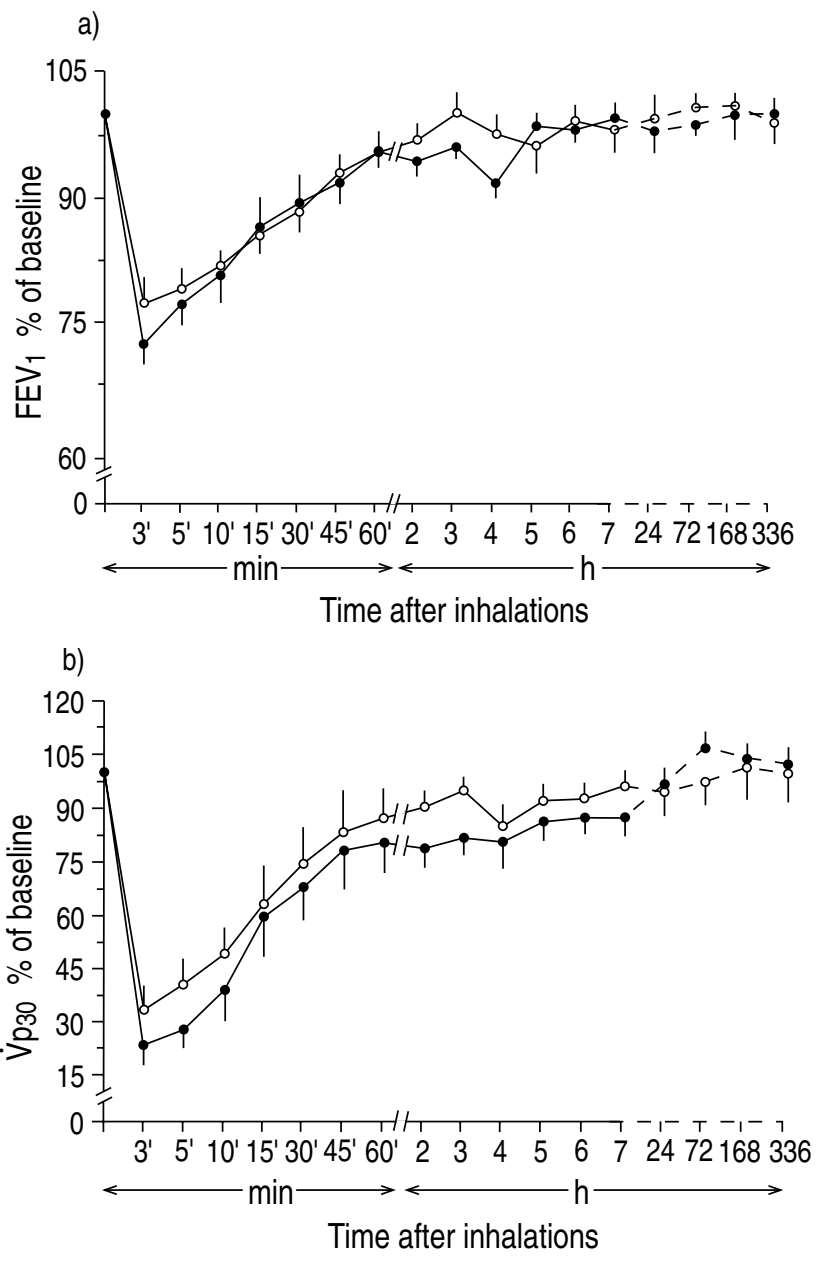

Fig. 2. - a) Effect of bradykinin $(-\bullet)$ and methacholine (- - ) in nine asthmatic subjects on forced expiratory volume in one second $\left(\mathrm{FEV}_{1}\right)$. Concentration of agonists used was the cumulative provocation concentration of agonist causing a $30 \%$ fall in $\mathrm{FEV}_{1}$ from baseline. Values are mean+/-sem. b) Effect of bradykinin (-๑) and methacholine (-o-) in nine asthmatic subjects on maximum expiratory flow rate at $70 \%$ of baseline vital capacity below total lung capacity during a partial forced expiratory manoeuvre $\left(\dot{\mathrm{V}} \mathrm{p}_{30}\right)$. Concentration of agonists used was the cumulative provocation concentration of agonist causing a $30 \%$ fall in $\mathrm{FEV}_{1}$ from baseline. Values are mean+/SEM.

at $60 \mathrm{~min}$ (fig. $2 \mathrm{a}$ and $\mathrm{b}$ ). There were no significant differences in the maximum falls of $\mathrm{FEV}_{1}$ achieved after bradykinin and methacholine, their falls being 28 and $24 \%$, respectively, (fig. 2a). Analyses of $\dot{\mathrm{V}} \mathrm{p}_{30}$ data showed a significant difference in the maximum falls induced by bradykinin and methacholine challenge, their falls being 77 and $67 \%$, respectively, ( $p=0.043$ ) (fig. $2 b$ ). With both agonists, there were no significant correlations between either the maximum percentage fall in $\mathrm{FEV}_{1}$ and baseline histamine $\mathrm{PC}_{20} \mathrm{FEV}_{1}$ or the maximum percent fall in $\dot{\mathrm{V}} \mathrm{p}_{30}$ and baseline $\mathrm{PC}_{40} \dot{\mathrm{V}} \mathrm{p}_{30}$. Bradykinin inhalation did not cause any late falls in $\mathrm{FEV}_{1}$ or $\dot{\mathrm{V}} \mathrm{p}_{30}$ (figs. 2a and b). The three subjects with moderately hyperresponsive airways (subjects Nos 1, 6 and 8) exhibited no difference in their responses to bradykinin when compared to the other six subjects, nor was there any significant difference between the bronchoconstrictor responses of the steroid and nonsteroid users. 


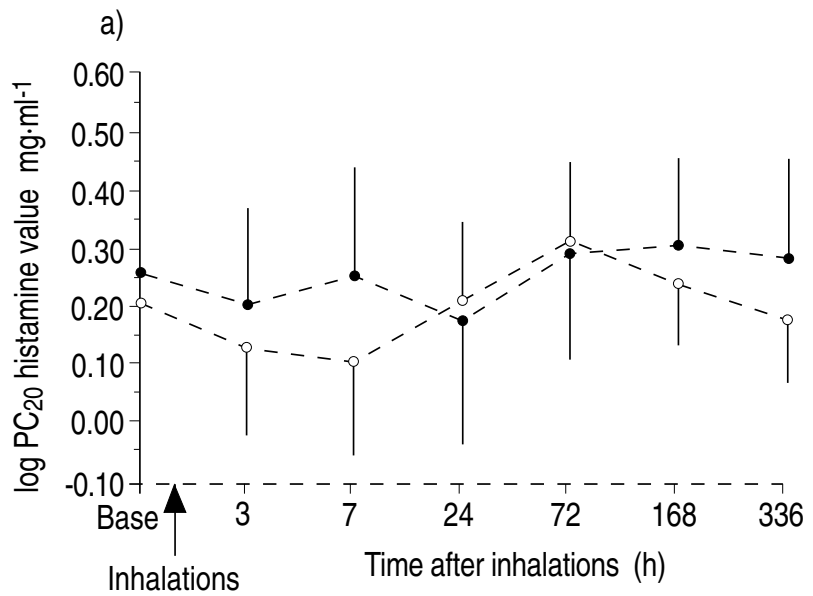

b)

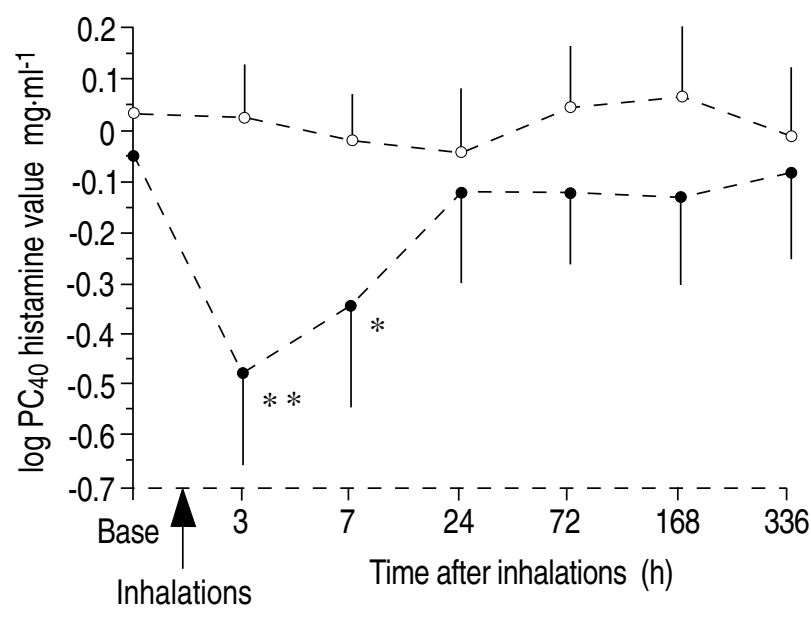

Fig. 3. - a) Effect of bradykinin ( $\bullet-)$ and methacholine ( - - $)$ on airways responsiveness to histamine measured as provocation concentrations of histamine causing a $20 \%$ fall in baseline $\mathrm{FEV}_{1}$ in nine asthmatic subjects. Values are mean+/-sEM. b) Effect of bradykinin $(-)$ ) and methacholine (-○) on airways responsiveness to histamine measured as provocation concentrations (PC) of histamine causing a $40 \%$ fall in baseline $\dot{\mathrm{V}} \mathrm{p}_{30}$ in nine asthmatic subjects. Values are means+/-sEM. **: $\mathrm{p}<0.01$ vs baseline and post-methacholine at $3 \mathrm{~h}$. *: $\mathrm{p}<0.05$ vs baseline and post-methacholine at $7 \mathrm{~h}$. For abbreviations see legend to figure 1 .

\section{Effect of bradykinin on histamine responsiveness}

No significant difference was observed between the airways responsiveness to histamine after bradykinin exposure or methacholine control challenge when expressed in terms of $\mathrm{PC}_{20} \mathrm{FEV}_{1}$ at any time-point postchallenge (fig. 3a). However, when airways responsiveness was monitored as $\mathrm{PC}_{40} \dot{\mathrm{V}} \mathrm{p}_{30}$, there were significant increases in histamine reactivity after bradykinin at 3 and $7 \mathrm{~h}$ when compared to the response after methacholine (placebo) (fig. 3b). The geometric mean $\mathrm{PC}_{40} \dot{\mathrm{V}} \mathrm{p}_{30}$ histamine values after bradykinin challenge decreasing from 1.06 to $0.33 \mathrm{mg} \cdot \mathrm{ml}^{-1}$ at $3 \mathrm{~h}(\mathrm{p}<0.01)$, and from 0.96 to 0.45 $\mathrm{mg} \cdot \mathrm{ml}^{-1}$ at $7 \mathrm{~h}(\mathrm{p}<0.05)$. The three subjects on regular inhaled corticosteroids (subjects Nos 6, 8 and 9) exhibited no difference in their airway responsiveness to histamine after bradykinin when compared to the other six subjects. No correlation could be established between the magnitude of bradykinin-induced bronchoconstriction and the bradykinin-induced change in histamine responsiveness.

\section{Discussion}

In this study, we have confirmed that inhaled bradykinin is a potent bronchoconstrictor with a rapid onset and brief duration of action in asthmatic subjects [14, 15]. In addition, no late response was observed. We have also shown that, in contrast to methacholine, inhalation of bradykinin caused a transient increase in bronchial responsiveness to histamine when expressed as $\mathrm{PC}_{40} \dot{\mathrm{V}}_{30}$ but not as $\mathrm{PC}_{20} \mathrm{FEV}_{1}$.

Since the use of flow rates from PEFV curves is said to better detect changes in the calibre of small rather than large airways [22], our findings suggest that bradykinin provokes a selective increase in peripheral airway responsiveness. Apart from being a very sensitive index of measuring the response to both bronchoconstrictor and bronchodilator agents [23, 24], flow rate values obtained from PEFV manoeuvres have the considerable advantage of not being affected by the possible artifacts associated with the deep inspiration which precede the maximal expiration for the recording of $\mathrm{FEV}_{1}$ (i.e. reflex bronchodilatation). The value of the observations on pharmacologically-induced changes in $\mathrm{PC}_{40} \dot{\mathrm{V}}_{30}$ to inhaled histamine depends on the reproducibility of this response. $\dot{\mathrm{V}}_{30}$ readings are highly repeatable with the technique used, because the calculated coefficient of variations ranged 5-13\%, which is in accordance with previously reported reproducibility limits [21, 24].

Although in asthmatic airways the bronchoconstrictor effect of bradykinin is likely to be mediated via a $\mathrm{B}_{2}$ receptor, as the $\mathrm{B}_{1}$ selective agonist [desArg $\left.{ }^{9}\right]$-bradykinin has no effect on airway function in asthmatic subjects [15], the precise mechanism by which kinins mediate bronchoconstriction in asthmatic subjects remains unclear. The mode of action of bradykinin in provoking bronchoconstriction in asthmatic subjects does not seem to involve the release of functionally active histamine [25], and the inhibition of cyclo-oxygenase by flurbiprofen or aspirin has little or no effect on the bronchoconstrictor response to bradykinin $[14,25]$. The potent anticholinergic agent, ipratropium bromide, produces an approximately five fold protection for the airways against bronchoconstriction provoked by bradykinin [14], indicating that cholinergic vagal reflexes may, in part, contribute to this response.

The present study is the first to report the airway effects of bradykinin on bronchial responsiveness in man. Bradykinin has been reported to contribute to the increase in bronchial reactivity that follows allergen challenge in sheep [19]. This effect is not related to changes either in airway smooth muscle or in muscarinic and histamine $\left(\mathrm{H}_{1}\right)$ receptor density or function, and is probably the consequence of the ability of a selective bradykinin antagonist to reduce pulmonary inflammation [26]. In contrast to these published studies, when data of the proximal 
airways $\left(\mathrm{FEV}_{1}\right)$ were included in the analysis, we failed to find any significant difference between changes in histamine responsiveness after inhaled bradykinin when compared with a similar initial bronchoconstrictor response provided by methacholine. The reason for this discrepancy is not clear. A precedent of this variable response has been reported in allergen-induced hyperresponsiveness that usually occurs in those who develop a late asthmatic response [7]. However, bradykinin did not produce a late response in any of our volunteers and it is consistent with the lack of subsequent increase in bronchial reactivity. The dose of bradykinin used in the present study might have been too low to elicit a detectable change in the $\mathrm{PC}_{20} \mathrm{FEV}_{1}$ histamine, but we cannot exclude the possibility that a higher dose or chronic exposure to this kinin could have been followed by a significant change in reactivity. To what extent the dose of bradykinin used might have affected our results is difficult to assess. However, consecutive challenges with bradykinin in asthmatic subjects failed to alter their airway responsiveness to histamine expressed as $\mathrm{PC}_{20} \mathrm{FEV}_{1}$ [27]. The subjects studied in the present investigation were a heterogenous group of atopic and nonatopic asthmatics, with a wide range in baseline bronchial responsiveness to histamine and in their use of inhaled corticosteroids. Comparison between subjects showed no difference in their airway responses to histamine after bradykinin exposure; thus, indicating that it is unlikely that the lack of bradykinin-induced changes in airway reactivity can be accounted for by differences in subjects characteristics.

However, when the effect of bradykinin on baseline airway reactivity was expressed as $\mathrm{PC}_{40} \dot{\mathrm{V}} \mathrm{p}_{30}$ histamine, a statistically significant increase in responsiveness was observed at 3 and $7 \mathrm{~h}$ postchallenge, thereby suggesting that the change in airway responsiveness after bradykinin exposure is peculiar to peripheral airways. All our subjects demonstrated a $40 \%$ fall in $\dot{\mathrm{V}} \mathrm{p}_{30}$ on all challenges to histamine and, therefore, the index of $\mathrm{PC}_{40} \dot{\mathrm{Vp}}_{30}$ acts as a reliable and sensitive index of bronchial responsiveness $[21,28]$. The change in histamine responsiveness observed was small but consistent. This small change would be unlikely to result in significant clinical symptoms, but the importance of this observation lies in the possible mechanism(s) of the increase in relation to the pathogenesis of airway hyperresponsiveness in asthma. It is unclear why the effect of bradykinin on histamine responsiveness was present only when $\mathrm{PC}_{40} \dot{\mathrm{V}} \mathrm{p}_{30}$ was used as an index of bronchial responsiveness. Although it cannot be excluded that this phenomenon might result from an artifact of the measurement, we believe that this is unlikely, since a similar change in $\mathrm{PC}_{40} \dot{\mathrm{V}} \mathrm{p}_{30}$ was not observed on the control study day with methacholine.

Bradykinin exposure may influence airway responses to histamine via three possible mechanisms. Firstly, it is possible that the change in responsiveness after bradykinin exposure is peculiar to peripheral airways due to regional difference in sensitivity [29]. Secondly, increased bronchial vascular permeability may lead to airway oedema and subsequent swelling of the airway walls, and may, therefore, affect baseline airway reactivity. In dogs, bradykinin is more potent than methacholine in inducing vasodilation and increase in the thickness of the airway mucosa [13], which is more significant in those parts of the airways where the ratio of change in mucosal thickness to the radius of adjacent lumen is large, such as in small conducting airways. A theoretical analysis suggests that a small increase in baseline airway calibre (i.e. due to mucosal thickening) might be expected to contribute to enhanced airway responsiveness for a given bronchoconstrictor stimulus, without any detectable change in resting lung function [30]. Using an elegant model that incorporates well-established fluid dynamic principles and detailed anatomical measurements of the airways, WigGs et al. [31] demonstrated that smooth muscle constriction alone produces only relatively modest increases in small airway resistance, whereas, when the same degree of constriction was coupled with airway wall thickening, dramatic increases in resistance were recorded. Thirdly, another speculative possibility that could explain the increase in airway responsiveness following bradykinin exposure is sensitization of sensory nerve endings to histamine. Bradykinin is known to directly stimulate airway C-fibres $[16,18]$. In guineapigs, a combination of atropine and capsaicin pretreatment largely abolishes the bronchoconstrictor response to instilled bradykinin, indicating that both a cholinergic reflex and release of neuropeptides from sensory nerves play a part [32]. Although sensory nerves sensitization is not known to occur in vivo, a recent study by DJUKANOvic et al. [33] has shown that inhaled allergen causes an upregulation of neuroeffector mechanisms in atopic asthmatics, reflected by a decrease in threshold for bradykinin stimulation. However, this does not explain the disparity in the response observed in this study with different indicators of bronchial reactivity.

In conclusion, our study showed that bradykinin exposure causes prompt bronchoconstriction, which was not followed by any significant late fall. When measured by the $\mathrm{PC}_{20} \mathrm{FEV}_{1}$ histamine, we were unable to demonstrate induction of airway hyperresponsiveness by bradykinin in this group of asthmatic volunteers. However, when the more sensitive index $\mathrm{PC}_{40} \dot{\mathrm{V}} \mathrm{p}_{30}$ histamine was used as a marker of bronchial responsiveness, a significant increase in airway reactivity was detected up to $7 \mathrm{~h}$, thus implicating bradykinin in the pathogenesis of airway hyperresponsiveness. This observation is of importance, because it provides a rational basis for the validation and the safe implementation of dose-response studies with inhaled bradykinin after pharmacological testing. However, none of the studies in humans have yet addressed the effects of bradykinin inhalation over prolonged periods, which for ethical reasons would be difficult to undertake, but is clearly a more relevant model of ongoing bradykinin formation in the inflamed airways of asthma. A more definitive understanding of the potential role of this mediator in the pathogenesis of airway hyperresponsiveness and asthma will only be possible once selective bradykinin receptor antagonists are made available for use in humans. 


\section{References}

1. Djukanovic R, Roche WR, Wilson JW, et al. Mucosal inflammation in asthma: state of the art. Am Rev Respir Dis 1990; 142: 434-457.

2. Boushey HA, Holtzman MJ, Sheller JR, Nadel JA. Bronchial hyperreactivity. Am Rev Respir Dis 1980; 121: 389-413.

3. Hargreave FE, Ryan G, Thomson NC, et al. Bronchial responsiveness to histamine or methacholine in asthma: measurement and clinical significance. J Allergy Clin Immunol 1981; 68: 347-355.

4. Chatham M, Bleeker ER, Smith PL, Rosenthal RR, Mason P, Norman PS. A comparison of histamine, methacholine and exercise airway reactivity in normal and asthmatic subjects. Am Rev Respir Dis 1982; 126: 235-240.

5. O'Byrne PM, Ryan G, Morris M, et al. Asthma induced by cold air and its relation to nonspecific bronchial responsiveness to methacholine. Am Rev Respir Dis 1982; 125: 281-285.

6. Boulet L-P, Cartier A, Thomson NC, Roberts RS, Dolovich J, Hargreave FE. Asthma and increases in nonallergic bronchial responsiveness from seasonal pollen exposure. J Allergy Clin Immunol 1983; 71: 399-406.

7. Cartier A, Thomson NC, Frith PA, Roberts R, Hargreave FE. Allergen-induced increase in bronchial responsiveness to histamine: relationship to the late asthmatic response and change in airway calibre. J Allergy Clin Immunol 1982; 70: 170-177.

8. Regoli D, Barabe J. Pharmacology of bradykinin and related peptides. Pharmacol Rev 1980; 31: 1-46.

9. Christiansen SC, Proud D, Cochrane CG. Detection of tissue kallikrein in the bronchalveolar lavage fluid of asthmatic subjects. J Clin Invest 1987; 75: 188-197.

10. Liu MC, Hubbard WC, Proud D, et al. Immediate and late inflammation responses to ragweed antigen challenge of the peripheral airways in allergic asthmatics: cellular, mediator and permeability changes. Am Rev Respir Dis 1991; 144: 51-58.

11. Christiansen SC, Proud D, Sarnoff RB, Juergens U, Cochrane CG, Zuraw BL. Elevation of tissue kallikrein and kinin in the airways of asthmatic subjects after endobronchial allergen challenge. Am Rev Respir Dis 1992; 145: 900-905.

12. Saria A, Lundberg JM, Skofitsch G, Lembeck F. Vascular protein leakage in various tissues induced by substance $\mathrm{P}$, capsaicin, bradykinin, serotonin, histamine and by antigen challenge. Naunyn Schmiedebergs Arch Pharmacol 1983; 324: 212-218.

13. Laitinen LA, Laitinen A, Widdicombe JG. Effects of inflammatory and other mediators on airway vascular beds. Am Rev Respir Dis 1987; 135: S67-70.

14. Fuller RW, Dixon CMS, Cuss FMC, Barnes PJ. Bradykinin-induced bronchoconstriction in humans: mode of action. Am Rev Respir Dis 1987; 135: 176-180.

15. Polosa R, Holgate ST. Comparative airway responses to inhaled bradykinin, kallidin and [desArg ${ }^{9}$-bradykinin in normal and asthmatic subjects. Am Rev Respir Dis 1990; 142: 1367-1371.

16. Davies B, Roberts AM, Coleridge HM, Coleridge JCG. Reflex tracheal gland secretion evoked by stimulation of bronchial C-fibres in dogs. J Appl Physiol: Respirat Environ Exercise Physiol 1982; 51: 985-991

17. Polosa R, Hasani A, Pavia D, et al. Acute effect of inhaled bradykinin on tracheobronchial clearance in normal humans. Thorax 1992; 47: 952-956.

18. Kaufman MP, Coleridge HM, Coleridge JCG, Baker DG. Bradykinin stimulates afferent vagal C-fibres in intrapulmonary airways in dogs. $J$ Appl Physiol: Respirat Environ Exercise Physiol 1980; 48: 511-517.

19. Soler M, Sielczak M, Abraham WM. A bradykinin antagonist blocks antigen-induced airway hyperresponsiveness and inflammation in sheep. Pulm Pharmacol 1990; 3: 9-15.

20. Polosa R. Role of the kinin-kallikrein pathway in allergic diseases. Allergy 1993; 48: 217-225.

21. Zamel N. Threshold of airway response to inhaled methacholine in healthy men and women. J Appl Physiol: Respirat Environ Exercise Physiol 1984; 56: 129-132.

22. Zamel N. Partial flow-volume curves. Bull Eur Physiopathol Respir 1984; 20: 471-475.

23. Bouhuys A, Hunt VR, Kim BM, Zapletal A. Maximum expiratory flow rates in induced bronchoconstriction in man. J Clin Invest 1969; 48: 1159-1168.

24. Barnes PJ, Gribbin HR, Osmanliey D, Pride NB. Partial flow-volume curves to measure bronchodilator doseresponse curves in normal humans. J Appl Physiol: Respirat Environ Exercise Physiol 1981; 50: 1193-1197.

25. Polosa R, Phillips GD, Lai CKW, Holgate ST. Contribution of histamine and prostanoids to bronchoconstriction provoked by inhaled bradykinin in atopic asthma. Allergy 1990; 45: 174-182.

26. Abraham WM, Burch RM, Farmer SG, Sielczak MW, Ahmed A, Cortes A. A bradykinin antagonist modifies allergen-induced mediator release and late bronchial responses in sheep. Am Rev Respir Dis 1991; 143: 787-796.

27. Polosa R, Rajakulasingam K, Prosperini G, Milazzo LV, Santonocito G, Holgate ST. Cross-tachyphylactic airway response to inhaled bradykinin, kallidin and [desArg']bradykinin in asthmatic subjects. Eur Respir J 1993; 6: 687-693.

28. Coleman H, Knox AJ, Britten JR, Tattersfield AE. Comparison of $\mathrm{PD}_{20} \mathrm{FEV}_{1}$ and $\mathrm{PD}_{40} \mathrm{Vp}_{30}$ as measurements of response to inhaled methacoline. Thorax 1988; 43: $867 \mathrm{p}$.

29. Wasserman MA, Mukherjee A. Regional differences in the reactivity of guinea-pig airways. Pulm Pharmacol 1988; 1: 125-131.

30. Moreno RH, Hogg JC, Paré PD. Mechanics of airway narrowing. Am Rev Respir Dis 1986; 133: 1171-1180.

31. Wiggs BR, Bosken C, Paré PD, James A, Hogg JC. A model of airway narrowing in asthma and in chronic obstructive pulmonary disease. Am Rev Respir Dis 1992; 145: 970-977.

32. Ichinose M, Belvisi MG, Barnes PJ. Bradykinin-induced bronchoconstriction in guinea-pig in vivo: role of neural mechanisms. J Pharmacol Exp Ther 1990; 253: $1207-1212$.

33. Djukanovic R, Polosa R, Holgate ST. The effect of bronchial allergen challenge on methacoline and bradykinin airway responsiveness. Eur Respir J 1991; 4: 340s. 